\title{
The Piúma lineament, southern Espirito Santo: structural expression and tectonic significance
}

\author{
O lineamento Piúma, sul do estado do Espírito Santo: \\ expressão estrutural e significado tectônico \\ Fernanda Silva Lourenço ${ }^{1 *}$, Fernando Flecha de Alkmim², \\ Mário Neto Cavalcanti de Araújo ${ }^{1}$, Marco Antonio Thoaldo Romeiro ${ }^{1}$, \\ Gabriel Correa de Matos ${ }^{1}$, Alvaro Penteado Crósta ${ }^{3}$
}

\begin{abstract}
The Piúma lineament, located in the Southern Espírito Santo State, Brazil, is one of the most prominent linear morphostructural features of the northern Mantiqueira Province. The lineament stands out in satellite images and topographic maps, extending for about $70 \mathrm{~km}$ in a $\mathrm{N} 50^{\circ} \mathrm{W}$ direction, between the towns of Iconha and Conceiçấo do Castelo (Espírito Santo). In order to investigate the nature and role played by the Piúma lineament in the tectonic evolution of the Mantiqueira Province and adjacent Campos Basin, we carried out a detailed structural analysis based on fieldwork, as well as geophysical data processing and interpretation. The results we obtained indicate that the Piúma lineament is a brittle shear zone characterized by N50W-trending and SW-dipping shear fractures, faults and joints. These structures record two distinct and incompatible motions, thereby recording the operation of two tectonic regimes: NNE-SSW extension and $\mathrm{E}-\mathrm{W}$ transtension. Comparing our results with the literature on the Southeastern Brazilian Continental Margin, we conclude that the Piúma lineament more likely developed after the Ediacaran Brasiliano orogenic event in response to an NNE-SSW extension, experiencing later a reactivation as normal dextral to dextral transtensional zone, probably in connection with the South Atlantic rifting in the Lower Cretaceous.
\end{abstract}

KEYWORDS: Remote sensing; Fractures; Paleostress analysis.
RESUMO: O lineamento Piúma, situado na porção sul do estado do Espírito Santo, está entre as feiçóes morfo-estruturais mais proeminentes da provincia Mantiqueira Setentrional. Constitui uma feiçāo linear regional, bem marcada em imagens de sensoriamento remoto e mapas topográficos, com aproximadamente $70 \mathrm{~km}$ de comprimento e direção $N 50^{\circ} \mathrm{W}$, entre as cidades de Iconha e Conceição do Castelo (Espírito Santo). Para investigar sua natureza e o papel que desempenha na evoluçäo tectônica da Provincia Mantiqueira e da bacia de Campos, adjacente, foi feita uma analise estrutural detalhada, levada a efeito através de trabathos de campo, processamento e interpretação de dados geofisicos. Os resultados obtidos indicam que o lineamento Piúma se traduz numa zona de cisalhamento rúptil, caracterizada pela presença de falhas e juntas com direçäo preferencial N50W e mergulho para SW. Essas estruturas registram a ação de dois movimentos distintos e incompativeis, que marcam a ação de dois regimes tectônicos: distensão NNE-SSW e transtração E-W. Comparando-se os resultados com a literatura disponivel para a margem continental sudeste brasileira, conclui-se que o lineamento Piúma, provavelmente, se desenvolveu em algum momento após o evento orogenético ediacarano Brasiliano, em resposta a uma distensão NNE-SSW, posteriormente sendo reativado como uma zona normal dextral a transtracional dextral, possivelmente relacionada à abertura do rifte do Atlântico Sul, no Cretáceo Inferior.

PALAVRAS-CHAVE: Sensoriamento remoto; Fraturas; Paleotensóes.

\footnotetext{
${ }^{1}$ Centro de Pesquisas e Desenvolvimento Leopoldo Américo Miguez de Mello - PETROBRAS/CENPES. E-mails: fernandalourenco@petrobras.com.br mario_araujo@petrobras.com.br,marcothoaldo@petrobras.com.br, gabriel.matos@petrobras.com.br

${ }^{2}$ Departamento de Geologia, Escola de Minas, Universidade Federal de Ouro Preto - UFOP. E-mail: ffalkmim@gmail.com

IInstituto de Geociências, Universidade Estadual de Campinas - UNICAMP. E-mail: alvaro@ige.unicamp.br

*Corresponding author

Manuscript ID: 20150038. Received in: 10/14/2015. Approved in: 10/04/2016.
} 


\section{INTRODUCTION}

The recognition of linear geomorphic features that could represent zones of weakness or displacements in Earth's crust was first reported by Hobbs (1912). Lineaments, as later defined by O'Leary et al. (1976), are linear or curvilinear features that potentially correspond to the surface expression of a fault or a zone of weakness. According the author, the structural displacement is not a requirement to characterize a feature as a lineament.

Sabins (1997) described long linear features in Precambrian shield areas that though clearly defined do not offset lithologic contacts. Similar features documented all over the world relates to weakness zones, in which the rocks are highly fractured and susceptible to erosion. Remote sensing imagery has been improved since the 1960's leading to an increase in the number of lineaments identified and investigated worldwide. Lineament analysis became an effective technique in structural and tectonic studies.

The study of the role played by basement structures, including lineaments, on the development and evolution of the Brazilian basins led to the basic conclusion that, as expected, Precambrian fabric elements underwent reactivation, locally exerting major controls on tectonic and sedimentary processes operating in the Phanerozoic (Cordani et al. 1984, Cunha 1985). Phanerozoic structures, on the other hand, may also overprint and significantly modify basement fabric elements.

The Piúma lineament, one of the most prominent linear features of northern Mantiqueira Province (Almeida \& Hasui 1984; Almeida et al. 2000) in Espírito Santo State, extends for over 70 kilometers in the $\mathrm{N} 50^{\circ} \mathrm{W}$ direction (Fig. 1), standing out in remote sensing imagery and topographic maps. Zalán and Oliveira (2009) and Tagliari et al. (2010) portrayed the lineament as a left-lateral strikeslip fault that, reaching the adjacent Campos continental margin basin, would offset salt domes and associated mini-basins. These authors also suggested that the Piúma fault together with another prominent linear feature of the province, the NNW-trending Colatina lineament system (Silva et al. 1987, Novais et al. 2004, Alkmim et al. 2013), could represent a new boundary between the Campos and Espírito Santo continental margin basins, instead of the Vitória High. Other authors, however, described the Piúma lineament as a fracture zone with small displacements and no clear relationship with offshore structures (Souza et al. 2012; Bronzoni 2011).

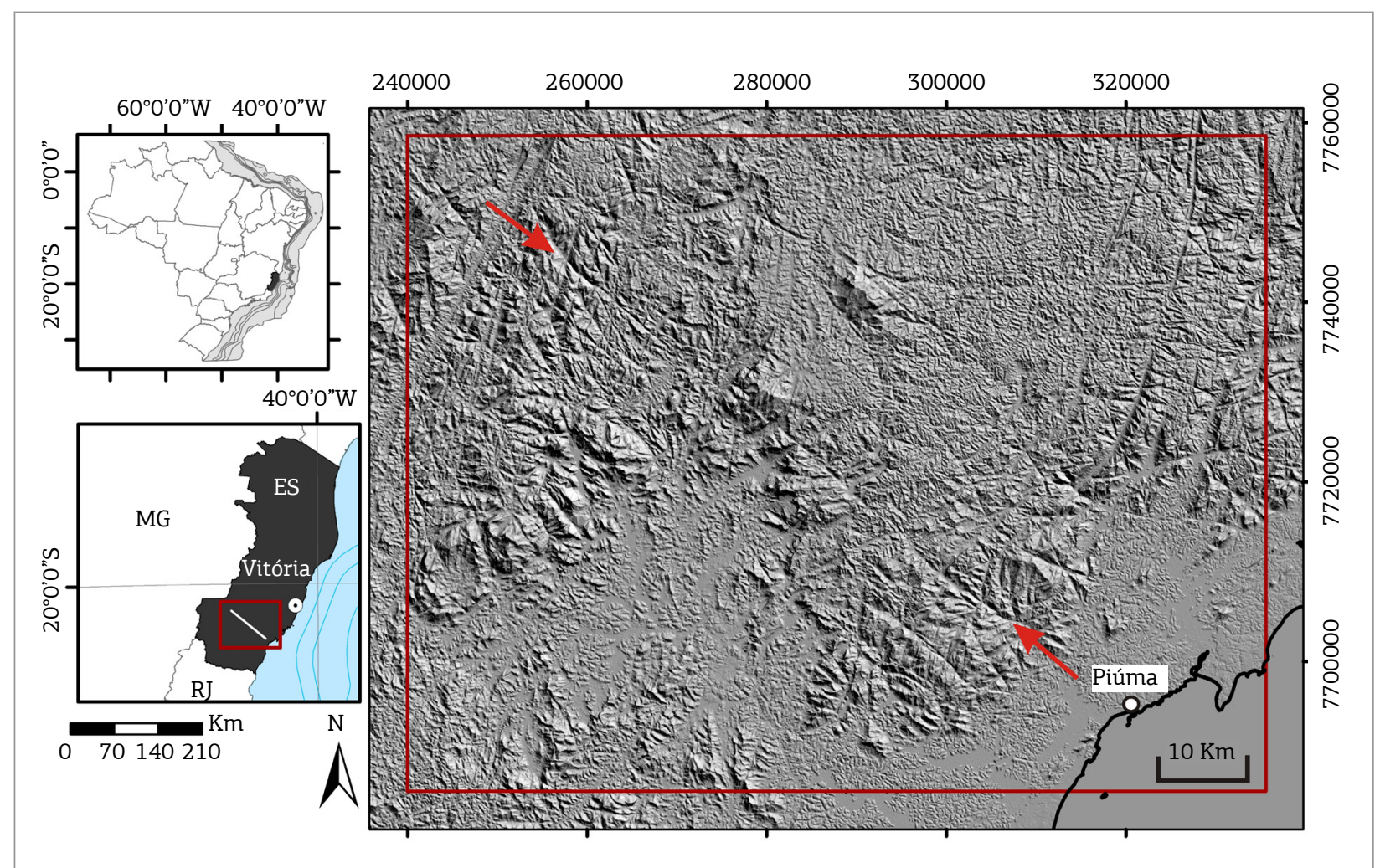

Figure 1. Shaded relief image generated with Shuttle Radar Topography Mission 1 Arc-Sec Global data (30m resolution) using a $45^{\circ}$ solar illumination angle at azimuth angle of $45^{\circ}$. The arrows point to the prominent Piúma lineament, which extends for over 70 kilometers in the southern Espírito Santo State, Brazil (SRTM 2000). 
We carried out a field-based study along Piúma lineament for paleostress analysis. In addition, we investigated its potential manifestations in the Campos offshore basin using seismic interpretation and potential field methods. We end this paper discussing the structural evolution of this lineament and interpreting its tectonic significance in this part of the Brazilian Continental Margin.

\section{METHODS}

We selected two areas for the study of the Piúma lineament. The former comprises a $95 \times 73 \mathrm{~km}$ area onshore in the Southern Espírito Santo State; the latter covers a 120 x $95 \mathrm{~km}$ offshore area in the Campos Basin.

The structural data obtained along the lineament and adjacent regions, which include 1.265 measurements of fractures and associated structures collected in 172 stations, was submitted to a paleostress analysis performed with the WinTensor software (Delvaux \& Sperner 2003).

The topographic data we used was obtained from the 1-Arc-Second Shuttle Radar Topography Mission (SRTM), an international project designed by the National Aeronautics and Space Administration (NASA) and the National GeospatialIntelligence Agency (NGA) to acquire radar data for the production of the first near-global set of land elevations. The data was processed using ArcMap ${ }^{\mathrm{TM}}$ software, in order to generate shaded relief images by changing the azimuth angle of the light source after the z-factor corrections for latitude $20^{\circ}$.

Magnetic data from Project 1093 (Espírito Santo) acquired by the Geological Survey of Brazil - Companhia de Pesquisa de Recursos Minerais (CPRM 2010) — was used to generate magnetic field anomaly maps, following the routines available on Oasis Montaj 8.2 software (Geosoft 2001). For the offshore study area, we have followed the same procedure with the data compiled by Oliveira and Santos (2001). We interpolated the data using the minimum curvature method (Briggs 1974) and then reduced to the pole, in order to eliminate the dipole effect (Baranov \& Naudy 1964). Fourier filters enhanced the magnetic anomalies.

We generated satellite-derived Bouguer gravity maps for both the onshore and offshore domains. For this purpose we used data from Global Marine Gravity V20 (Sandwell \& Smith 2009) and Global Topography V15 (Smith \& Sandwell 1997), considering a sediment/water density contrast of $970 \mathrm{~kg} / \mathrm{m}^{3}$. We also generated a Bouguer anomaly map to investigate the shallow structures, associated to the basement framework, by subtracting an upward continuation filter with a $5 \mathrm{~km}$-wavelength from another with a $30 \mathrm{~km}$-wavelength.

Ten 2D seismic sections in two-way traveltime were chosen out of 20 lines provided by the National Agency of Petroleum, Natural Gas and Biofuels (ANP) database (Banco de Dados de Exploração e Produção - BDEP) (Lourenço 2015). The lines, which cover the selected portion of the offshore Campos Basin, were processed and interpreted using Petrel Software (Tab. 1, Fig. 2).

\section{GEOLOGICAL SETTING}

The Piúma lineament is located in the southern Araçuaí orogen at the transition zone to the Ribeira orogenic belt. The Araçuaí orogen, together with the West Congolian belt of central West Africa resulted from the closure of the terminal branch of the Neoproterozoic Adamastor Ocean in the course of the West Gondwana assembly by the end of the

Table 1. Seismic lines provided for interpretation by the National Agency of Petroleum, Natural Gas and Biofuels - ANP)

\begin{tabular}{l|c|c|c|c|c}
\hline Survey & Segment & Year & Domain & Line type & Orientation \\
\hline 0038_CAMPOS_10A & $0038-0251$ & 1973 & Time & Strike & NE-SW \\
\hline 0066_CAMPOS_1A & $0066-0009$ & 1981 & Time & Dip & WNW-ESE \\
\hline 0066_CAMPOS_1A & $0066-0035$ & 1981 & Time & Strike & NE-SW \\
\hline 0066_ESPIRITO_SANTO_2A & $0066-0032$ & 1981 & Time & Strike & NE-SW \\
\hline 0066_ESPIRITO_SANTO_2A & $0066-0033$ & 1981 & Time & Strike & NE-SW \\
\hline 0228_NW_ALBACORA_5A & $0228-0469$ & 1997 & Time & Dip & ENE-WSW \\
\hline 0231_BAIXO_SAO_TOME_3A & $0231-0384$ & 1989 & Time & Strike & NE-SW \\
\hline 0259_2D_SPP_2Q_1999 & SPP99-2107 & 2000 & Time & Strike & NNW-SSE \\
\hline 0259_2D_SPP_2Q_1999 & SPP99-2223 & 2000 & Time & Dip & NW-SE \\
\hline 0259_2D_SPP_2Q_1999 & SPP99-2319 & 2000 & Time & Strike & NE-SW \\
\hline
\end{tabular}


Ediacaran and beginning of Cambrian (Pedrosa-Soares et al. 2001). The transition zone between the Araçuaí and Ribeira orogens occurs along latitude $21^{\circ} \mathrm{S}$, where NS-trending structures of the Araçuaí orogen bends toward northeast and merge with fabric elements of the Ribeira orogen (Pedrosa-Soares \& Noce 1998; Pedrosa-Soares \& Wiedemann-Leonardos 2000; Pedrosa-Soares et al. 2001).

According to Vieira et al. (2014) (Fig. 3), the portion of the Araçuaí orogen we selected for studying the Piuma lineament exposes the following lithostratigraphic units:

- the Paleoproterozoic Serra do Valentim basement complex;

- Neoproterozoic metasedimentary and metavolcanic arc-related rocks of Bom Jesus do Itabapoana and Rio Doce Groups;

- Neoproterozoic meta-volcanosedimentary rocks of the São Fidelis and Italva groups, as well as the high grade Nova Venécia Complex, which together represent backarc basin fill units; and

granitic rocks of the G1, G2, G3 and G5 supersuites, which record magmatic events of the pre, syn and post-collisional development stages of the Araçuaí orogen between 630 and $490 \mathrm{Ma}$ (Pedrosa-Soares et al.2011).

The main structural elements of the southern Araçuaí orogen are NE-striking and WNW-verging folds and thrust shear zones overprinted in variable degrees by dextral transpressional structures of the same orientation (Fig. 3) (Cunningham et al. 1998, Peres et al. 2004, Alkmin et al. 2007, Silva 2010). In outcrop-scale, the dominant structure is a SE-dipping schistosity or gneissic foliation $\left(s_{n}\right)$ associated to a conspicuous down-dip stretching lineation $\left(l_{n}\right)$. In domains intensively affected by the late-stage dextral transpression, the $s_{\mathrm{n}}$ foliation becomes progressively steeper and a new low rake and N-plunging stretching lineation develop on its surface. Along the thrust and dextral strike-slip shear zones the country rocks are converted into mylonites. Examples of this process can be illustrated by the prominent dextral strike-slip Guaçuí and Batatal shear zones (Fig. 3), which are marked by up to 250 m-thick bands of mylonites.

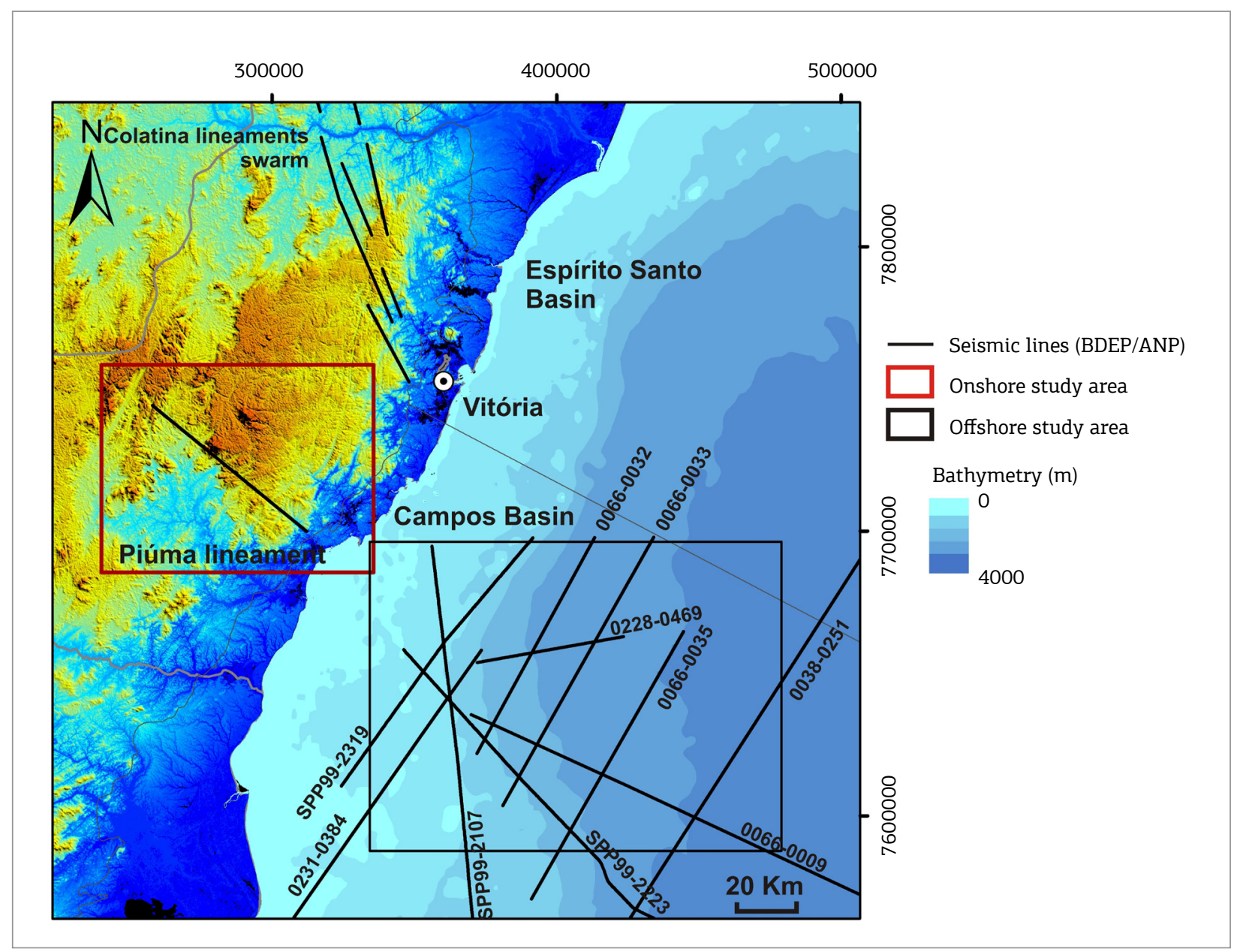

Figure 2. Seismic lines used in this study. 
The offshore area of our study (Fig. 2) encompasses a portion of the Lower Cretaceous Campos basin (Ojeda 1982; Guardado et al. 1989). The Vitória basement high separates the Campos and Espírito Santo basins (Fig. 4). The Cabo Frio high marks its southern boundary to the Santos basin. The Campos fault, oriented parallel to the coastline, delimitates two major tectonic compartments of the basin: the shallower western sector, characterized by thicker continental crust, and deeper eastern sector, which is underlain by a considerably thinner continental crust segment (Guardado et al. 1989). According to Guardado et al. (2000), the main structural elements of the Campos basin are rift-related NEto NW-trending horsts and grabens, pre-Aptian structures related to the Campos fault, and the province of salt domes located in deep waters (Fig. 4).

The continental rift megasequence of the Campos basin is composed of Barremian lacustrine rocks (Guardado et al. 2000), deposited on top of Neocomian subalkaline basalts, dated between 130 to $120 \mathrm{Ma}$ (Fodor et al. 1983, Thomaz-Filho 1984; Mizusaki 1986). An erosion surface, the "pre-Alagoas unconformity", marks the end of the rift phase in the Campos basin. The transition to passive margin marine stage is recorded by Albian shallow-water carbonates and siliciclastic turbidities (Guardado et al. 1989, 2000). The Campos basin fill units record basic volcanism events that persisted until the Eocene (Pereira et al. 1986).

The structures formed during the South Atlantic rift phase follow the NE- structural trend of the Precambrian basement, like the present-day coastline. The majority of these structures was generated in response to a WNW-ESE-oriented extensional stress field (Szatmari \& Moriak 1995, Ernesto 2007, Eagles 2007, Stanton et al. 2010) and created half grabens filled with alluvial fans and lacustrine sediments (Novais et al. 2004). Secondary rift faults are oriented in the NW and EW directions and apparently experienced many reactivations that controlled the sediment deposition and oil migration during the post-rift stage (Novais et al. 2004). In general, the NW-oriented structures in the Southeastern Brazilian Margin are interpreted as transfer zones (Macedo 1987, Almeida \& Carneiro 1998, Cobbold et al. 2001, Meisling et al. 2001, Eagles 2007, Souza 2008, Stanton et al. 2010) related to the oblique rifting.

The Piúma lineament was first recognized in GEMS-1000 radar images from the RADAMBRASIL Project (Projeto RADAMBRASIL 1983). The lineament was later interpreted as a left-lateral strike-slip fault by the Brazilian Geological Survey team (Féboli \& Padilha 1992, Silva 1993).

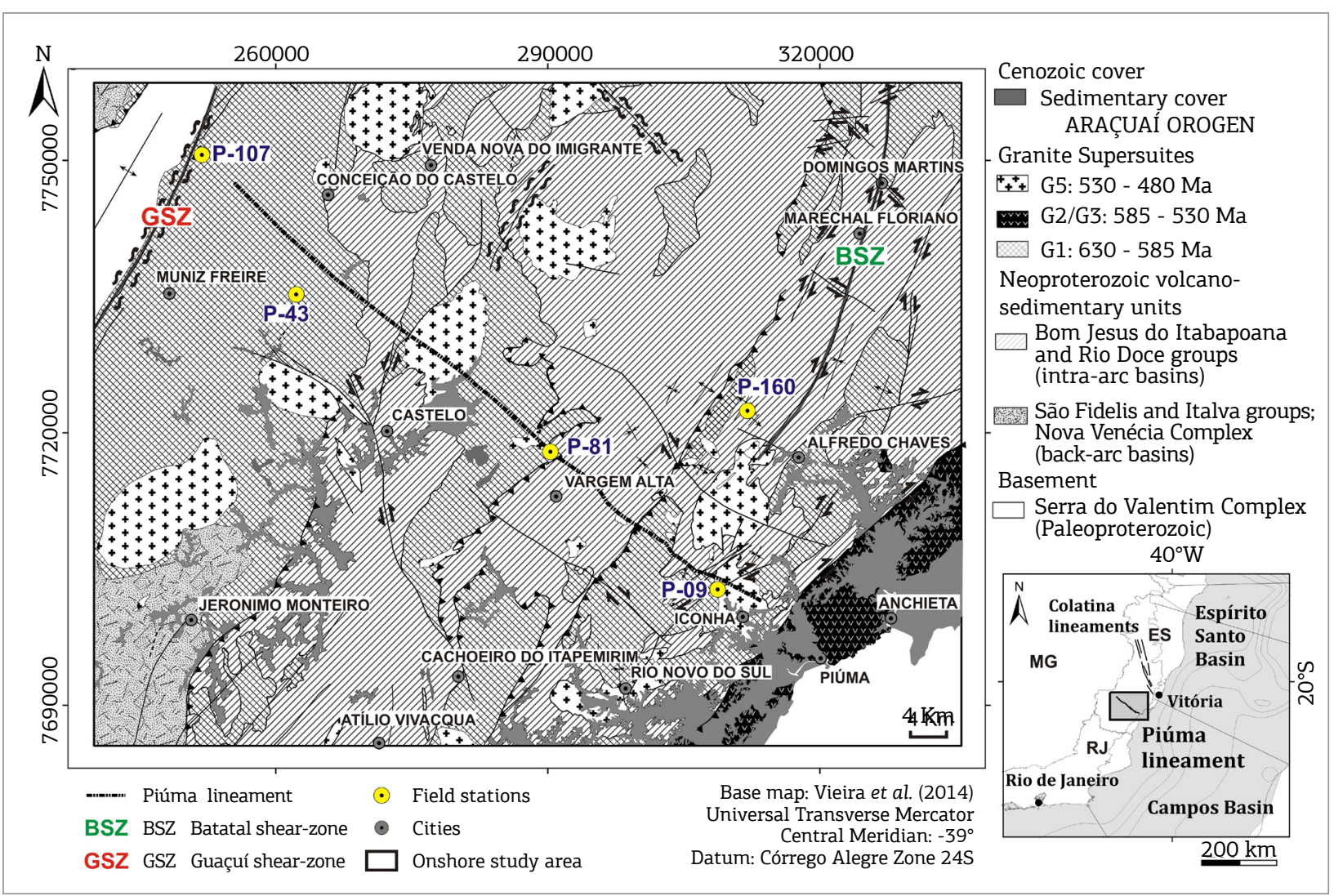

Figure 3. Geological map of the onshore study area showing the main lithostratigraphic units and structural elements of the Araçuaí orogen (Adapted from Vieira et al. 2014). 
More recently, in a study conducted by PETROBRAS and the São Paulo State University (UNESP), the Piúma lineament was described as a fracture zone enlarged by differential erosion, with no appreciable displacement (Bronzoni 2011, Souza et al. 2012).

\section{THE QUEST FOR THE GEOPHYSICAL EXPRESSION OF THE PIÚMA LINEAMENT}

The digital elevation model generated from SRTM data (Fig. 1) clearly shows the NW-striking Piúma lineament, which extends for over $70 \mathrm{~km}$ between the towns of Iconha in the southeast, and Conceição do Castelo in the northwest (Fig. 3). When examined in more detail, the lineament is locally discontinuous and made up of several $\mathrm{N} 50^{\circ} \mathrm{W}$-trending segments. Like a few equally oriented features, the Piúma lineament truncates the frankly dominant $\mathrm{N} 30^{\circ}-40^{\circ} \mathrm{E}$-trending lineaments that correspond to the country rock fabric elements. Other sets of linear features present in the image are NNW- and EW-oriented. The NNW set, concentrated in the northeastern portion of the study area, is related to the Colatina lineament system (Fig. 2), another prominent feature affecting the basement in the Araçuaí orogen (Silva et al. 1987, Novais et al. 2004, Alkmin et al. 2013).

Filtered magnetic field anomaly maps obtained for the onshore domain (Fig. 5) show that the major anomalies

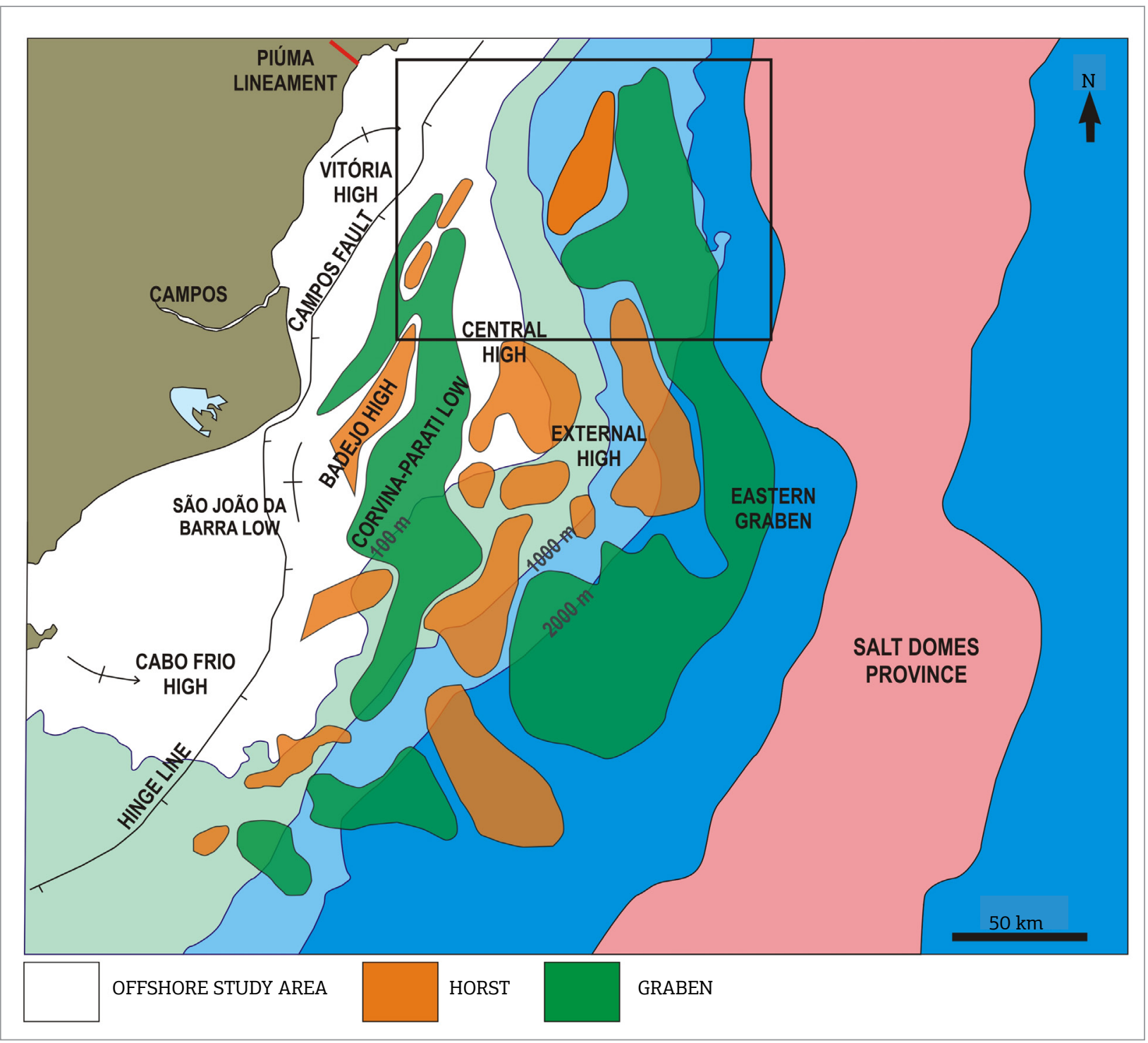

Figure 4. Main structural elements of the rift section in the Campos Basin: northeast- and northwest-trending horsts and grabens mapped at the Neocomian basalt reflector. Pre-Aptian structures related to the Campos fault. The salt dome province in ultra-deep water. (Adapted from Rangel \& Martins 1998 and Guardado et al. 2000). 


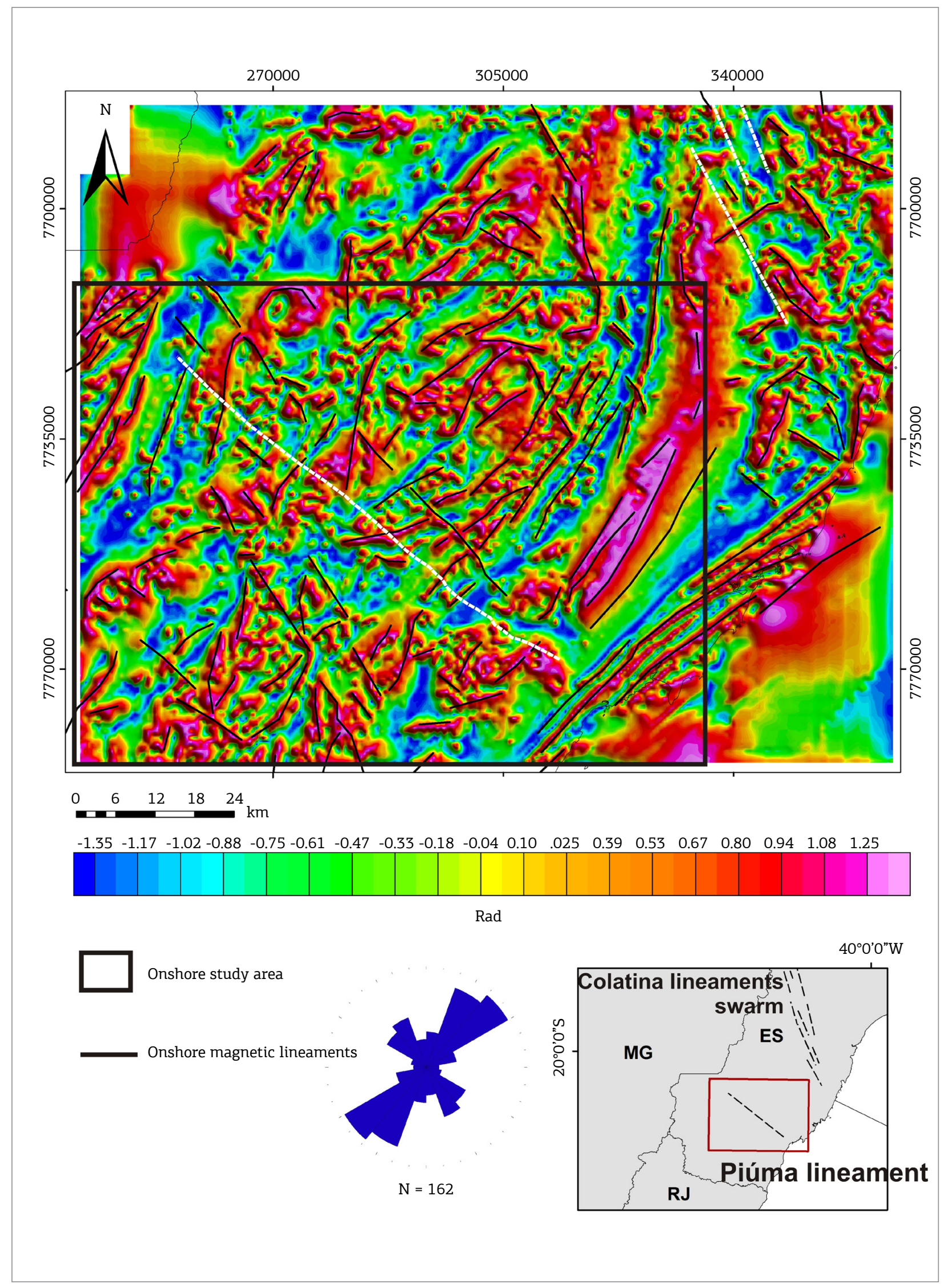

Figure 5. Filtered onshore magnetic field anomaly map showing that the major anomalies in the study area are NE-trending. 
trend NE and coincide with the Guacuí and Batatal shear-zones (Fig. 3). The presence of granite plutons is also well marked by high positive circular anomalies, which coincide with the G5 Supersuite intrusions. The small wavelength anomalies along the Colatina lineament system seem to reflect the associated mafic dike swarm. Worth noting, the Piúma lineament has no expression in these maps. Lourenço (2015) tried to estimate the structure depth using the Euler deconvolution, a semi-quantitative technique performed with the onshore magnetic data. Once again, the author did not find any evidence for the presence of the of the Piúma lineament at depths. The onshore gravity data from the Brazilian gravimetric network (Rede Gravimétrica Fundamental Brasileira - RGFB), made available by the Brazilian Institute of Geography and Statistics (Instituto Brasileiro de Geografia e Estatística - IBGE) is largely spaced and do not provide elucidative information at the scale of this work.

As shown on Figure 6, the offshore residual Bouguer anomaly map reflects the major structural compartments of the Campos Basin, which are separated by a strong positive anomaly following the Cretaceous hinge zone along the Campos fault (Fig. 4). The negative anomalies are related to depocenters and salt domes. The positive anomalies in general reflect the presence of basement highs and igneous bodies. Remarkably, there is no evidence for a structure : that could represent an offshore continuation of the Piúma lineament.

The dominant elements of the filtered magnetic field anomaly maps generated for the offshore domain exhibit $\mathrm{N} 20^{\circ}-40^{\circ} \mathrm{E}$ preferred orientations, also reflecting the basement tectonic framework. Again, the Piúma lineament does not find an expression in these maps. Some strong positive anomalies in the northeast portion of the basin seem to be related to Eocene volcanic edifices.

Strike-oriented seismic lines available for the Campos basin show a relatively large group of normal faults affecting the basement units, and a smaller group of faults of the same nature cutting post-Aptian sediments (Fig. 7). Dip oriented seismic sections reveal a series of blocks bounded by normal faults that dip ESE and WNW. These sections also show that the salt volume increases toward east. Normal faults are linked to the upper portion of salt domes and salt walls affect the overlying sediments. The extension of the Piúma lineament towards the basin interior falls on a relatively large NW-trending basement high, which does not exhibit any internal structure that could possibly represent its continuation. In sum, our quest for the geophysical expression of the Piúma lineament in the continent and adjacent Campos Basin revealed unsuccessful.

\section{THE PIÚMA LINEAMENT IN THE FIELD}

In the field, the manifestation of the Piúma lineament is a series of deep and NW-aligned valleys, with an average width of ca. $250 \mathrm{~m}$, in which the southwest wall is significantly steeper than the opposite wall. Sediments often fill these valleys (Fig. 8).

The structure behind the Piúma lineament is a steeply SW-dipping fracture zone, whose components are preferentially oriented in the $\mathrm{N} 50^{\circ} \mathrm{W}$ direction. The fracture system includes steeply dipping to vertical structures, which are (Fig. 9):

- widely spaced (metric) joints, a few of them apparently filled by deeply weathered mafic dikes; and

- faults and shear fractures associated with slickensides, fault gouges, chlorite coatings and tension gashes in echelon arrays. The faults show centimeter-scale offsets and the motions inferred from kinematic indicators vary from normal-sinistral, sinistral, and normal-dextral. The same motions are recorded in the shear-fracture surfaces.

Brittle structures near the lineament define three other sets of joints and shear fractures oriented in the NE, EW and NS directions (Fig. 10A). The NE-trending set strikes $\mathrm{N} 30^{\circ}-45^{\circ} \mathrm{E}$ and comprises closely spaced joints $(0.05-1 \mathrm{~m}$ apart) and shear fractures with slickensides, which indicate normal-dextral to normal motions. These structures are oriented parallel to the regional foliation and developed through brittle reactivation of the preexisting ductile structures. Fractures of this set are often confined to some lithotypes, as dikes and veins cutting granitoids and gneisses. The NS set is composed mainly of high angle striated shear fractures, along which the dominant shear sense is normal-sinistral. The EW set includes tensile fractures and tension gashes that strike $\mathrm{N} 70^{\circ} \mathrm{W}$ to $\mathrm{N} 85^{\circ} \mathrm{E}$. The tension gashes often occur in echelon arrays defining N50W-striking sinistral shear zones.

\section{PALEOSTRESS ANALYSIS}

Fault data with slip lines (slickensides) were grouped into families with common geometrical characteristics and analyzed together with tension fractures using the WinTensor software developed by Delvaux and Sperner (2003). The analysis of the fracture data set (Fig. 10A) revealed the existence of two kinematically incompatible groups of structures. The first group (Fig. 10B) is composed of steeply dipping normal-sinistral to sinistral shear fractures of the Piúma set $\left(\mathrm{N} 50^{\circ} \mathrm{W}\right)$, EW-striking joints, and normal to normal dextral 
NE-oriented shear fractures. The second group (Fig. 10C) includes elements of the Piúma set that show normal-dextral sense of shear, NS-trending joints, as well as associated NS-trending shear fractures recording normal to normal-sinistral senses of motion (Fig. 11A).

For the first group of fractures, the inversion procedure yielded a stress field, in which $\sigma_{3}$ and $\sigma_{2}$ are horizontal and oriented in the NNE and WNW directions, respectively. In this scenario, $\sigma_{1}$ is vertical, thus, characterizing an extensional tectonic regime coupled to a minor strike-slip component (Fig. 11B). The second group of structures characterizes a stress field defined by horizontal EW-trending $\sigma_{3}$, and horizontal NS-oriented $\sigma_{1}$. In this case, $\sigma_{2}$ is vertical, indicating a transtensional tectonic regime (Fig. 11C).

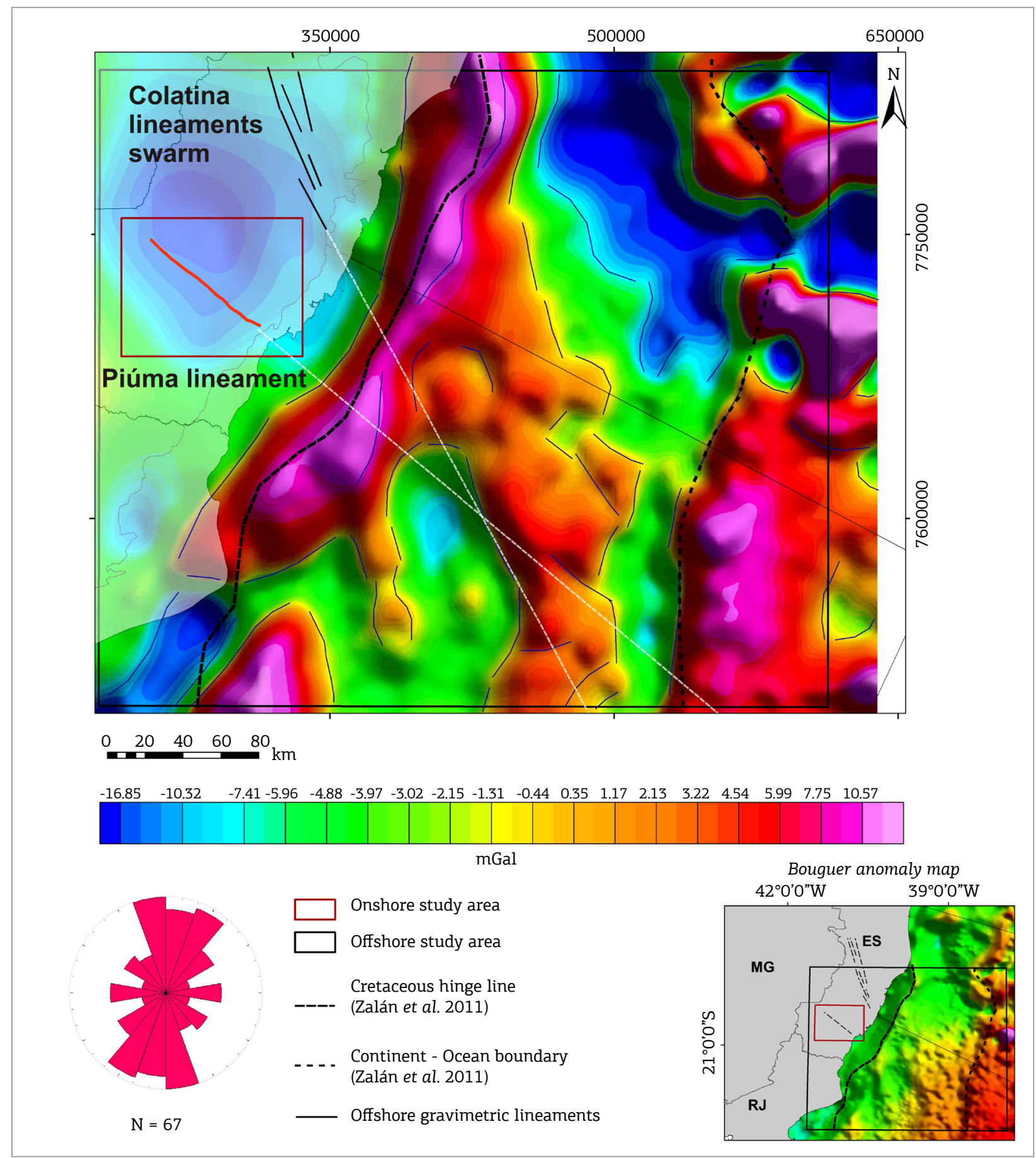

Figure 6. Offshore residual Bouguer anomaly map with the major NE trend structural elements of the Campos basin. Cretaceous hinge line and continent-ocean boundary traces from Zalán et al. (2011). 


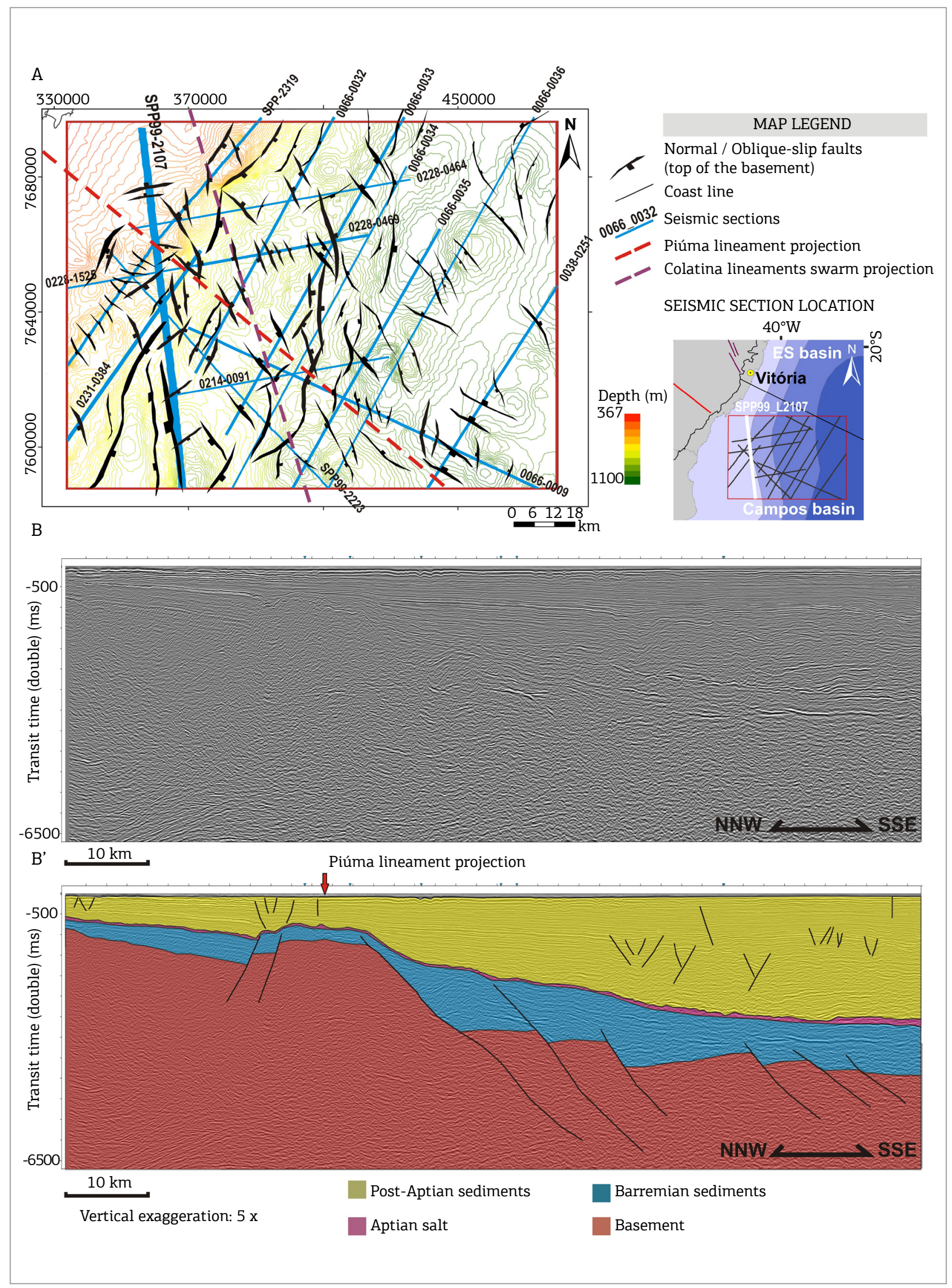

Figure 7. (A) Offshore structural map of the study area showing the normal to oblique-slip faults that dip ESE and WNW. Modified from Guardado et al. (1989). (B) A strike seismic line (SPP99-2107) revealing the presence of a NW-SE-oriented basement high coincident with the Piúma lineament projection in the Campos Basin (B'). 


\section{TECTONIC SIGNIFICANCE OF THE PIÚMA LINEAMENT: A DISCUSSION}

The results we obtained indicate that the Piúma lineament corresponds to a N50W-striking and SW-dipping brittle shear zone, whose dominant components are normal to normal sinistral faults as well as shear fractures and nearly vertical joints. The remarkable morphologic expression of the lineament in remote sensing imagery and topographic maps can be explained by the fact that the highly fractured zones are more susceptible to erosion, as emphasized by Sabins (1997). Our investigation on the offshore area did not indicate that the Piúma brittle shear zone extends into the Campos Basin.

As previously pointed out, the Piúma lineament and the surrounding region contain two groups of kinematically incompatible brittle structures, indicating that after nucleation the lineament and the fractures present in the study

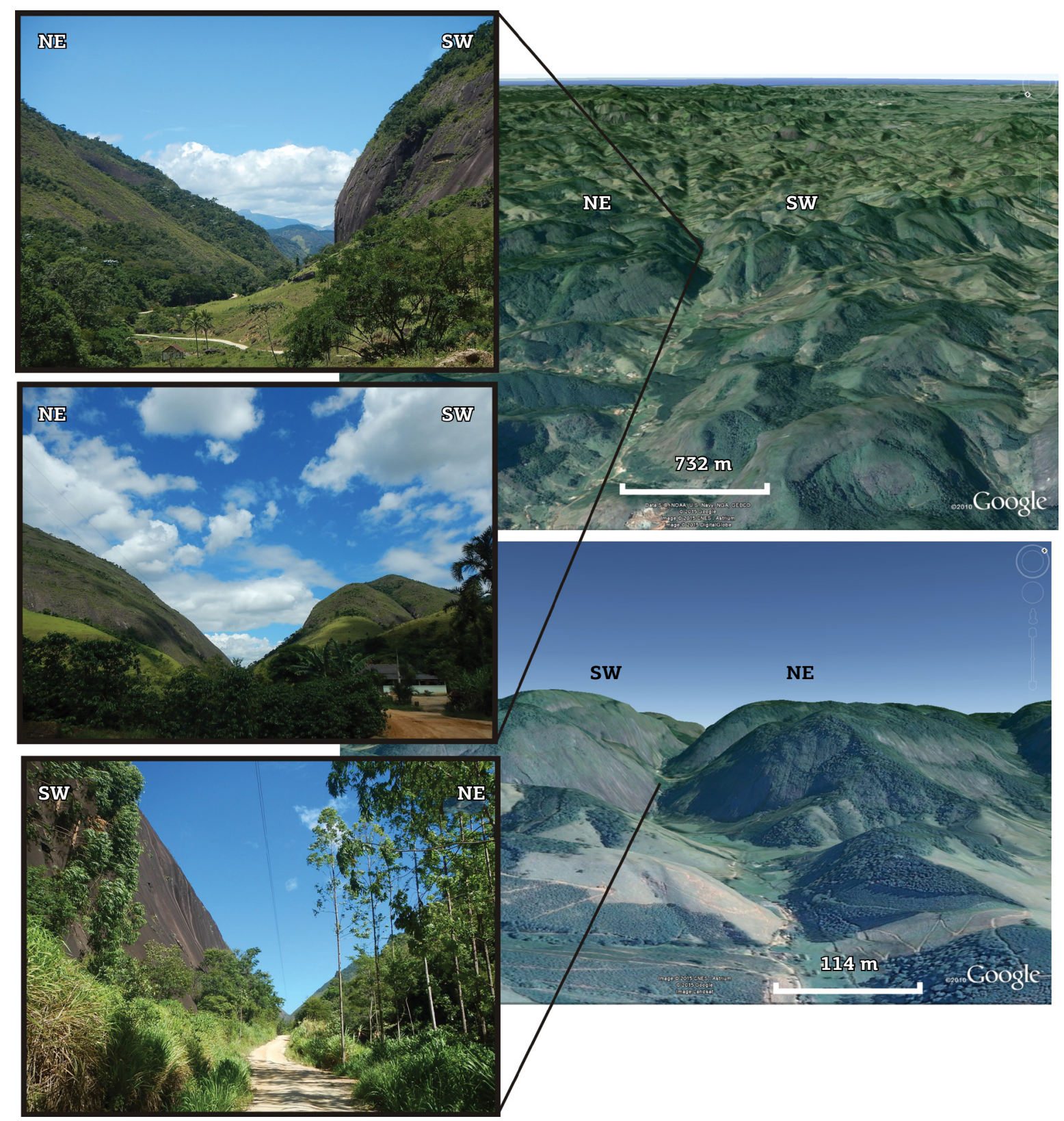

Figure 8. Geomorphologic expression of the Piúma lineament. Note the NE-facing asymmetry of the hills, with a steeper southwest wall (Google 2015). 
area underwent at least one reactivation episode. These structures record the action of two distinct tectonic regimes: an extensional with a minor strike-slip component, and a transtensional stress field. Which regime was responsible for the nucleation of the Piúma lineament? Due to absence of clear crosscut relationships between the elements of the two families of structures, this question cannot be answered alone by the data obtained in the field.
Tectonic studies in Southeastern Brazil (Almeida et al. 1999, Riccomini et al. 2004, Alkmin et al. 2013) indicate that Ediacaran NW- to NNW-trending fracture zones and mafic dykes nucleated in an extensional regime and reactivated as dextral strike-slip zones during the South Atlantic rifting in the Lower Cretaceous. Furthermore, several NW-trending structures in the Southeastern Brazilian Margin were interpreted as transfer
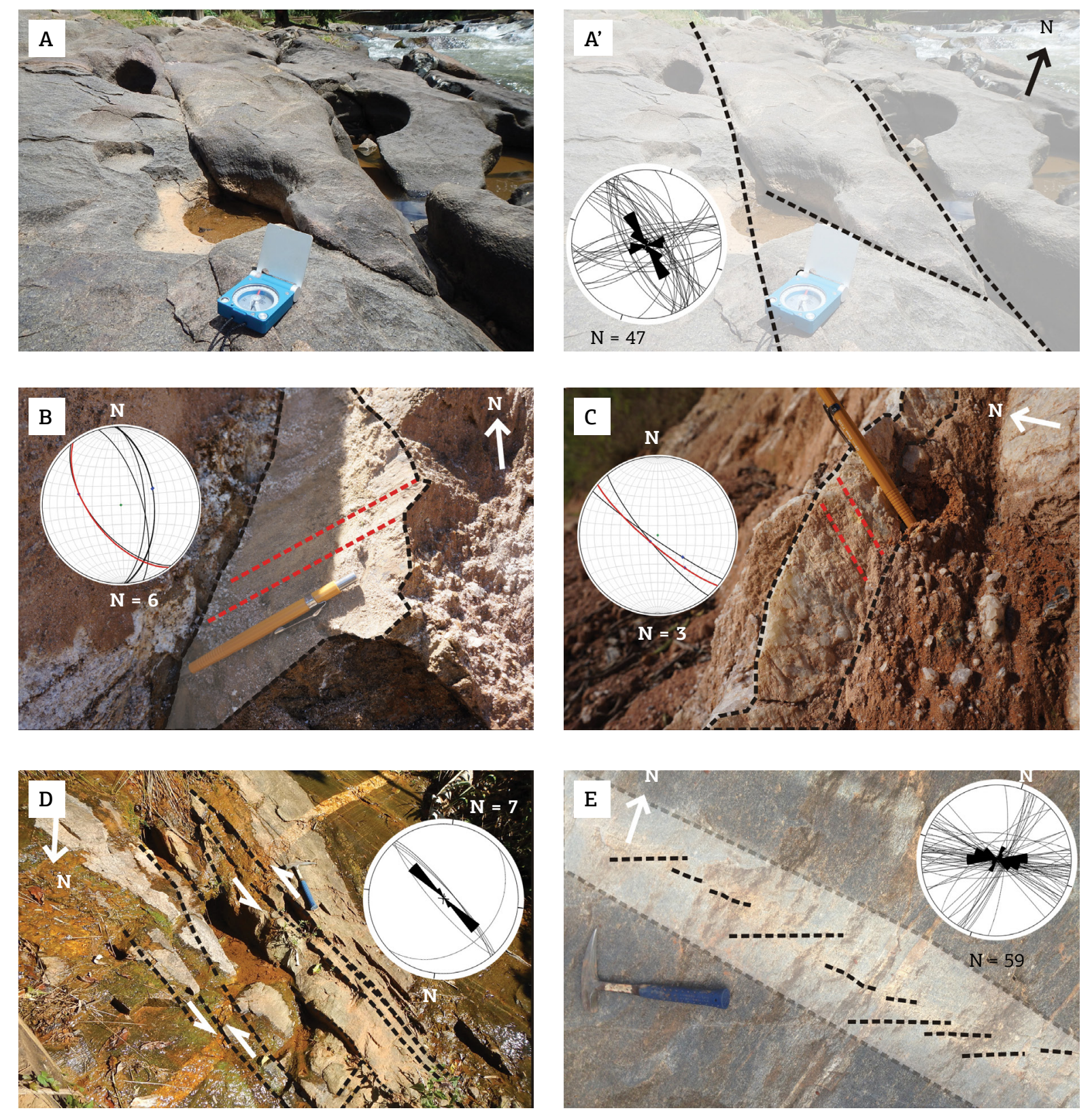

Figure 9. NW-SE-trending fracture set. (A) and (A') depicts widely spaced (metric) joints, from P-09 station. (B) Shear-fractures (233/59) with slickensides (287/44) in quartzite from P-160 (normal-dextral). (C) Shearfractures (214/85) with slickensides (131/55) in quartzite from P-81 (normal sinistral). (D) Sub-vertical quartz vein (N28E) in granodiorite dislocated by NW-SE shear-fractures suggesting sinistral strike-slip displacement in P-107 station. (E) Tension gashes in hydrotermalized NW-SE zone indicating sinistral displacement. 


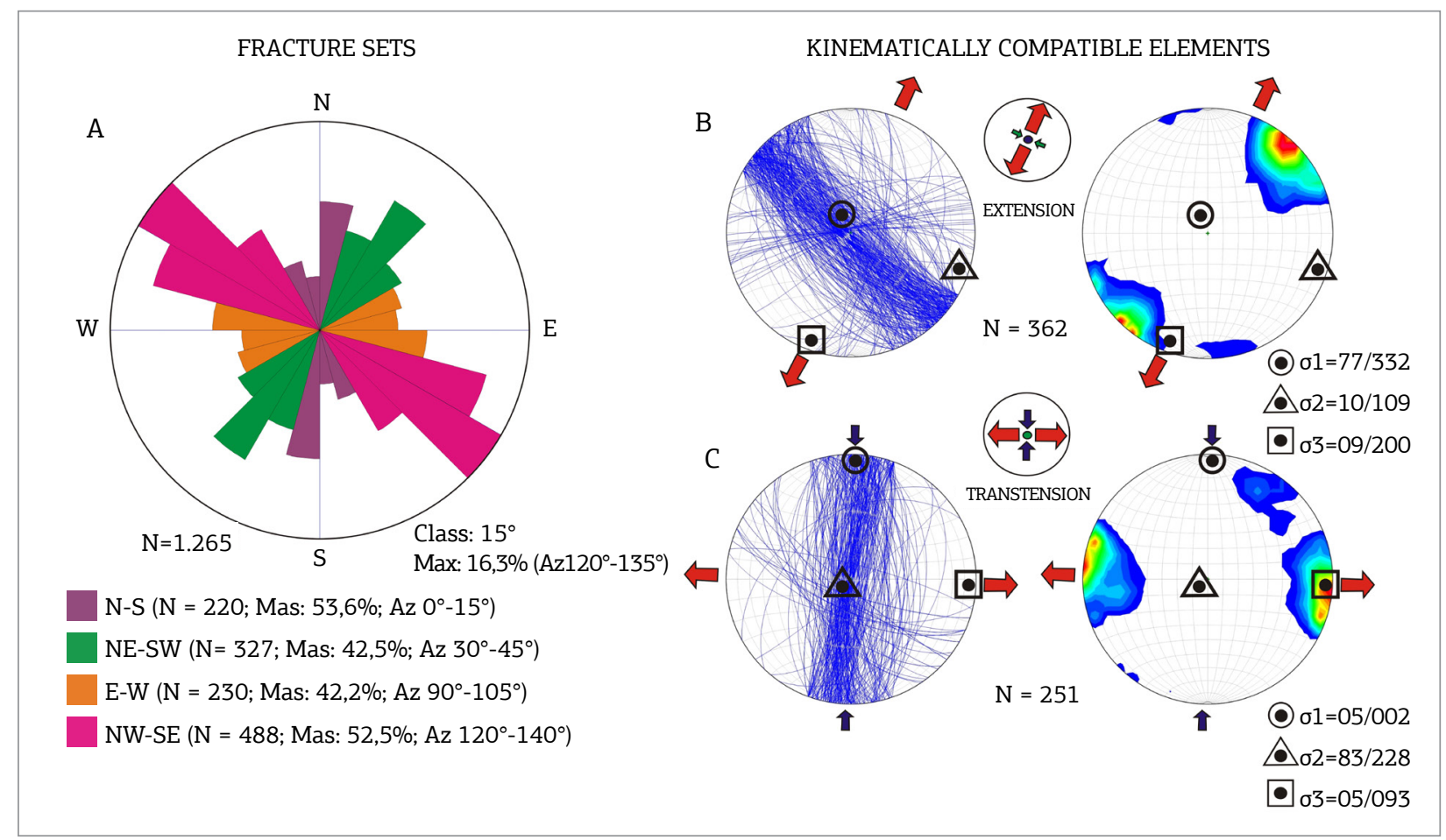

Figure 10. (A) Main fracture sets. (B) Stereonet plots (Schmidt, lower hemisphere) of planes and poles to planes of the first group of kinematically compatible elements. (C) Second group of kinematically compatible elements.

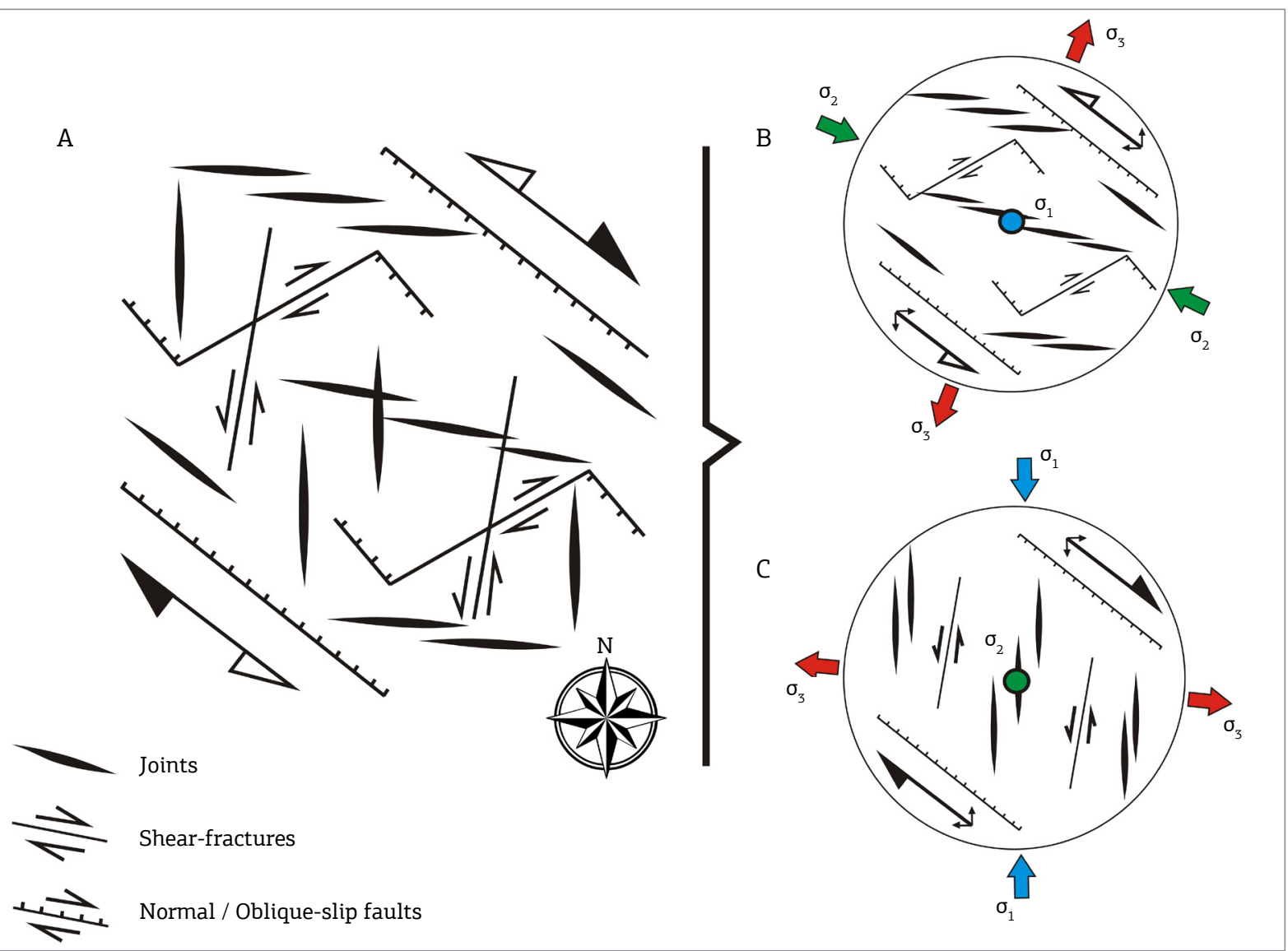

Figure 11. (A) Schematic diagram showing the kinematically inconsistencies among the fracture sets. (B) First group of fractures, related to an extensional tectonic regime coupled to a minor strike-slip component. (C) Second group of fractures, compatible with a transtensional tectonic regime. 
zones (Szatmari \& Moriak 1995, Eagles 2007, Souza 2008, Stanton et al. 2010, Cobbold et al. 2001, Meisling et al. 2001). These zones record dextral strike-slip displacement during the Lower Cretaceous rifting event and were later reactivated under the same stress regime (Macedo 1987, Almeida \& Carneiro 1998). The dextral strike-slip regime predicted for the NW-trending structures of the South Atlantic rifting event is compatible with the transtensional tectonic regime revealed by the paleostress analysis. Thus, the Piúma lineament more likely nucleated as NW-trending and SW-dipping normal to normal-sinistral fracture zone and later underwent an overall normal-dextral to normal displacement during the development and evolution of the Brazilian Eastern Margin.

\section{CONCLUSIONS}

The study we conducted on the Piúma lineament led to the following conclusions:

the lineament is the land surface expression of a $70 \mathrm{~km}$ long brittle shear zone composed of a series of $\mathrm{N} 40^{\circ}-60^{\circ} \mathrm{W}$-striking and preferentially SW-dipping shear fractures, faults and joints;

- the analysis we performed in the geophysical anomaly maps of the Campos Basin did not indicate the existence of any structure that could possibly represent an extension of the lineament in the offshore domain;

the fractures that define the lineament and affect the country rocks in adjacent areas record the action of two distinct tectonic regimes: a NNE-SSW extensional, coupled to a minor strike-slip component, and an EW-oriented transtension;

neither absolute nor relative ages of these regimes could be determined using the data we obtained from the field structural analysis and geophysical methods;

a comparison of our results with the literature data available for the Southern Brazilian Margin suggests that the Píuma lineament more likely nucleated as a NW-trending and SW-dipping normal to normal-sinistral fracture zone and later underwent an overall normal-dextral to normal motion during the development and evolution of the Brazilian eastern marginal basins;

\section{ACKNOWLEDGEMENTS}

The authors would like to acknowledge financial support provided by PETROBRAS and the geophysical data made available by CPRM and ANP. Reviews and suggestions provided by Rômulo Machado, Pedro Victor Zalán and anonymous reviewers greatly improved the original manuscript.

\section{REFERENCES}

Alkmim F.F., Pedrosa-Soares A.C., Noce C.M., Cruz S.C.P. 2007. Sobre a evolução tectônica do orógeno Araçuaí-Congo Ocidental. Geonomos, 15(1):25-43.

Alkmim F.F., Pedrosa-Soares A.C., Roncato J., Gradim C., Belém J., Voll E. O Feixe de Lineamentos Colatina - Relatório Conjunto dos Projetos "Caracterização Morfoestrutural e Geológica do Feixe de Lineamentos Colatina" e "Investigação Estrutural do Feixe de Lineamentos Colatina”. Cooperação entre a UFOP e a UFMG no âmbito da Rede de Estudos Geotectônicos da Petrobras. Belo Horizonte: CPMTC/IGC/ UFMG/; Ouro Preto: DEGEO/EM/UFOP. 58p. 2013. Relatório Interno.

Almeida F.F.M. \& Hasui Y. 1984. O embasamento da Plataforma Sul Americana. In: O Pré-Cambriano do Brasil. São Paulo, Ed. Edgard Blucher, p. 1-5

Almeida F.F.M. \& Carneiro C.D.R. 1998. Origem e evolução da Serra do Mar. Revista Brasileira de Geociências, 28(2):135-150.

Almeida F.F.M., Brito Neves B.B.B., Carneiro C.D.R. 2000. The origin and evolution of the South American Plataform. Earth-Science Reviews, 50(1-2):77-111.

Almeida J., Eirado L.G., Dios F., Gontijo A., Heilbron M., Valeriano C. 1999. A Zona de Fraqueza Crustal de Barra Mansa. In: Simpósio de Geologia do Sudeste, 6, Boletim de Resumos, 96 p.

Baranov V. \& Naudy H. 1964. Numerical calculation of the formula of reduction to the magnetic pole. Geophysics, 29(1):67-79.
Briggs I.C. 1974. Machine contouring using minimum curvature. Geophysics, 39(1):39-48.

Bronzoni L. 2011. Caracterização estrutural do lineamento de Piúma e sua influência na porção norte da bacia de Campos. Monograph, Instituto de Geociências e Ciências Exatas, Universidade Estadual Paulista, Rio Claro, 89 p.

Cobbold P.R., Meisling K.E., Mount V.S. 2001. Reactivation of an obliquely rifted margin, Campos and Santos basins, southeastern Brazil. American Association of Petroleum Geologists Bulletin, 85(11):1925-1944

Cordani U.G., Brito-Neves B.B, Fuck R.A., Porto R., Thomaz Filho A., Cunha F.M.B. 1984. Estudo Preliminar de integração do PréCambriano com os eventos tectônicos das bacias sedimentares brasileiras. Rio de Janeiro, PETROBRAS, CENPES. SINTEP. 70 p.

CPRM - Serviço Geológico do Brasil. 2010. Projeto Aerogeofísico Espírito Santo: Relatório Final do Levantamento e Processamento dos Dados Magnetométricos e Gamaespectométricos. Prospectors Aerolevantamentos e Sistemas Ltda. Ministério de Minas e Energia, Secretaria de Geologia, Mineração e Transformação Mineral. Texto e Anexo (Mapas), v. 1, Rio de Janeiro. 206 p.

Cunha F.M.B. Integração das bacias do litoral do sul da Bahia e do Espírito Santo com a faixa Pré-Cambriana adjacente. Rio de Janeiro: PETROBRAS/CENPES. 50p. (Rel. 650-07959). 1985. Relatório Interno. 
Cunningham W.D., Alkmim F.F., Marshak S. 1998. A structural transect across the coastal mobile belt in the Brazilian Highlands (latitude $20^{\circ} \mathrm{S}$ ): the roots of a Precambrian transpressional orogen. Precambrian Research, 92(3):251-275.

Delvaux D. \& Sperner B. 2003. New aspects of tectonic stress inversion with reference to the TENSOR program. In: Nieuwland D.A. (ed.) New insights into structural interpretation and modelling. Geological Society, London, Special Publications, 212:75-100.

Eagles G. 2007. New angles on South Atlantic opening. Geophysical Journal International, 168(1):353-361.

Ernesto M. 2007. Drift of South America Platform since Early Cretaceous: reviewing the apparent polar wander path. Geociências, 25(1):83-90

Féboli W.L \& Padilha A.V. 1992. Folha SF.24-V-A-VI, Piúma. Belo Horizonte, Programa Levantamentos Geológicos Básicos do Brasil, CPRM. $114 \mathrm{p}$

Fodor R.V., McKee E.H., Asmus H.E. 1983. K-Ar ages and the opening of the South Atlantic Ocean: basaltic rock from the Brazilian margin. Marine Geology, 54(1-2):M1-M8

GEOSOFT. 2001. Magmap - 2D Frequency Domain Processing Geosoft Technical Note, $34 \mathrm{p}$

Google. 2015. Google Earth. Version 6.0.3.2197. Vargem Alta, Espírito Santo. Avaiable at: www.google.com/earth/ [cited at Jun. 2015].

Guardado L.R., Gamboa L.A.P., Lucchesi C.F. 1989. Petroleum geology of the Campos Basin, Brazil, a model for a producing Atlantic type Basin. In: Edwards J.D. \& Santogrossi P.A.(eds.) Divergent/passive margin basins. American Association Petroleum Geologists Memoir, 48:3-19.

Guardado L.R., Spadini A.R., Brandão J.S.L., Mello M.R. 2000. Petroleum system of the Campos Basin. In: Mello M.R. \& Katz B.J. (eds.) Petroleum systems of South Atlantic margins: American Association Petroleum Geologists Memoir, 73:317-324.

Hobbs W.H. 1912. Earth features and their meaning. Macmillan, New York, 506 p.

Lourenço F.S. 2015. O lineamento Piúma: características gerais e história evolutiva no cenário tectônico da Província Mantiqueira Setentrional e margem continental. MS Dissertation, Departamento de Geologia, Escola de Minas, Universidade Federal de Ouro Preto, $125 \mathrm{p}$.

Macedo J.M. 1987. Evolução estrutural da Bacia de Santos e áreas continentais adjacentes. MS Dissertation, Departamento de Geologia, Escola de Minas, Universidade Federal de Ouro Preto, Ouro Preto, 173 p. Meisling K.E., Cobbold P.R., Mount V.S. 2001. Segmentation of an obliquely rifted margin, Campos and Santos basins, Southeastern Brazil. American Association of Petroleum Geologists Bulletin, 85(11):1903-1924

Mizusaki A.M.P. 1986. Rochas ígneo-básicas do Neocomiano da Bacia de Campos. Caracterização e comportamento como reservatório de hidrocarbonetos. MS Dissertation, Instituto de Geofísica, Universidade Federal do Rio de Janeiro, Rio de Janeiro, 104 p.

Novais L.C.C., Teixeira L.B., Neves M.T., Rodarte J.B.M., Almeida J.C.H., Valeriano C.M. 2004. Novas ocorrências de diques de diabásio na faixa Colatina - ES: estruturas rúpteis associadas e implicações tectônicas para as bacias de Campos e do Espírito Santo. Boletim de Geociências da Petrobras, 12(1):191-194.

Ojeda H.A.O. 1982. Structural framework, stratigraphy and evolution of Brazilian marginal basins American Association of Petroleum Geologists Bulletin, 66(6):732-749

O'Leary D.W., Friedman J.D., Pohn H.A. 1976. Lineament, linear, lineation: some proposed new standars for old terms. The Geological Society of America Bulletin, 87(10):1463-1469.
Oliveira J.A.B. \& Santos E. Atlas da margem continental sudeste: integração dos dados batimétricos, gravimétricos e magnéticos. Rio de Janeiro: PETROBRAS. 2001. Relatório Interno.

Pedrosa-Soares A.C. \& Noce C.M. 1998. Where is the suture zone of the Neoproterozoic Araçuaí-West Congo orogen? In: Conference on Basement Tectonics, 14, Ouro Preto, Extend Abstracts, 35-37.

Pedrosa-Soares A.C \& Wiedemann-Leonardos C.M. 2000. Evolution of the Araçuaí Belt and its connection to the Ribeira Belt, Eastern Brazil. In: Cordani U., Milani E., Thomaz-Filho A. \& Campos D.A. (eds.) Tectonic Evolution of South America. Sociedade Brasileira de Geologia, p. 265-285.

Pedrosa-Soares A.C., Noce C.M., Wiedemann C.M., Pinto C.P. 2001 The Araçuaí-West Congo orogen in Brazil: an overview of a confined orogen formed during Gondwanaland assembly. Precambrian Research, 110:307-323.

Pedrosa-Soares A.C., De Campo C.P., Noce C., Silva L.C., Novo T., Roncato J., Medeiros S., Castañeda C., Queiroga G., Dantas E. Dussin I., Alkmim F. 2011. Late Neoproterozoic-Cambrian granitic magmatism in the Araçuaí orogen (Brazil), the Eastern Brazilian Pegmatite Province and related mineral resources. Geological Society Special Publications, 350:25-51.

Pereira M.J., Barbosa C.M., Agre J., Gomes J.B., Aranha L.G.F., Saito M., Ramos M.A., Carvalho M.D., de Stamato M., Bagni O. 1986 Estratigrafia da Bacia de Santos: análise das sequências, sistemas deposicionais e revisão litoestratigráfica. In: Congresso Brasileiro de Geologia, 34, Anais, 1:65-79.

Peres G.G., Alkmim F.F., Jordt-Evangelista H. 2004. The southern Araçuaí belt and the Dom Silvério Group: Geologic architecture and tectonic significance. Anais da Academia Brasileira de Ciências, 76(4):771-790

Projeto RADAMBRASIL. 1983. Geologia, geomorfologia, pedologia, vegetação e uso potencial da terra. Folhas SF23/SF24. Rio de Janeiro. $780 \mathrm{p}$.

Riccomini C., Sant'Anna L.G., Ferrari A.L. 2004. Evolução Geológica do Rifte Continental do Sudeste do Brasil. In: Mantesso-Neto V. Bartorelli A., Dal Ré Carneiro C. \& Neves B.B.B. (orgs.). Geologia do Continente Sul-Americano: Evolução da obra de Fernando Flávio Marques de Almeida. Beca, p. 383-405.

Sabins F. 1997. Remote Sensing: principles and interpretation. $3^{\text {rd }}$ Edition. New York: W.H Freeman and Company, 494p.

Sandwell D.T. \& Smith W.H.F. 2009. Global Marine gravity from retracked Geosat and ERS-1 altimetry: Ridge segmentation versus spreading rate. Journal of Geophysical Research, 114(1):1-18.

Silva C.M.T. 2010. O sistema transcorrente da porção sudeste do Orógeno Araçuaí e norte da Faixa Ribeira: Geometria e significado tectônico. PhD Thesis, Universidade Federal de Ouro Preto, Ouro Preto, $221 \mathrm{p}$

Silva J. M.R., Lima M.I.C., Veronese V.F., Ribeiro Junior R.N., SigaJúnior O. 1987. Geologia. In: Projeto Radambrasil. Folha Rio Doce (SE. 24). Rio de Janeiro. IBGE, v. 34

Silva J.N. 1993. Cachoeiro do Itapemirim. Programa Levantamentos Geológicos Básicos do Brasil. Folha SF.24 VAV. Brasília: CPRM, 163p.

Smith W.H.F. \& Sandwell D.T. 1997. Global sea floor topography from satellite altimetry and ship depth soundings. Science, 277(5334):1956-1962

Souza I.A. 2008. Falhas de transferência da porção norte da bacia de Santos interpretadas a partir de dados sísmicos: sua influência na evolução e deformação da bacia. PhD Thesis, Instituto de Geociências e Ciências Exatas, Universidade Estadual Paulista, Rio Claro, $202 \mathrm{p}$ 
Souza I.A., Soares Jr. A.V., Machado F.B., Fernandes M.A., Cardozo T., Salamuni E., Neves M.A., Antonialli R.C., Simões L.S.A. Estudos estruturais e paleotectônios dos riftes na margem continental entre as bacias do Espírito Santo e Pelotas, construção da base de tecnologia da informação e georreferenciamento dos produtos integrados e sua preparação para a base de dados VGE e SIGEO. Relatório do Projeto RIFTE/UNESP. Cooperação entre PETROBRAS e UNESP, no âmbito do Programa de Fronteiras Exploratórias (PROFEX). Rio Claro: UNESP. 225p. 2012. Relatório Interno.

SRTM - Shuttle Radar Topography Mission 1 Arc-second Global. 2000. Available at: https://ta.cr.usgs.gov/SRTM1Arc. [cited at jan. 2015]

Stanton N.,SchmittR., Galdeano A., Maia M., Mane M. 2010. Crustal structure of the southeastern Brazilian margin, Campos Basin, from aeromagnetic data: New kinematic constraints. Tectonophysics, 490(1-2):15-27.

Szatmari P. \& Moriak W.U. 1995. Plate model of post-breakup tectono-magmatic activity in SE Brazil and the adjacent Atlantic. In: Simp. Nac. Estudos Tectônicos, 5, Gramado, Anais, 1:213-214.

Tagliari C.V, Fontes F.T., Alves R.G., Silva A.L, França R.L., Oliveira Filho A.G., Andrade A.A. 2010. Proposta de novo limite geológico das bacias sedimentares de Espírito Santo e Campos a partir da análise da influência da tectônica do embasamento (porções emersa e submersa) na coluna sedimentar offshore. In: Congresso Brasileiro de Geologia, 45, Belém, Anais.
Thomaz-Filho A. Datação radiométrica de rochas vulcânicas básicas da Bacia de Campos: PETROBRASCENPES, 104, 1-3. 1984. Relatório Interno.

Vieira V.S, Silva M.A., Corrêa T.R., Lopes N.H.B. 2014. Mapa geológico do Espírito Santo. Escala 1:400.000. Programa Integração, geologia e recursos minerais do estado do Espírito Santo. Belo Horizonte: CPRM.

Zalán P.V \& Oliveira J.A.B. Arcabouço estrutural das bacias de Campos e Espírito Santo - Proposição de novo limite geológico para as bacias. Simpósio de Geologia do Embasamento (Interno/PETROBRAS). Rio de Janeiro. 2009. Relatório Interno.

Zalán P.V. Severino M.D.C.G., Rigoti C.A., Magnavita L.P., Oliveira J.A.B., Viana A.R. 2011. An entirely new 3D-view of the crustal and mantle structure of a South Atlantic passive margin - Santos, Campos and Espírito Santo Basins, Brazil. In: AAPG Annual Convention and Exhibition, Houston, Texas, USA, Expanded Abstract, p. 1-12.

Available at www.sbgeo.org.br 